\title{
The Centrality of Near-Death Experiences in Chinese Pure Land Buddhism
}

\author{
Carl B. Becker \\ Department of Philosophy \\ Southern Illinois University
}

\section{INTRODUCTION}

The field of near-death studies has burgeoned since Raymond Moody Jr. (1975) published his ground-breaking studies of neardeath experiences. One of the commonest reactions to the visionary experiences of heaven by the critical observer has been to argue that these are nothing more than the projections of the expectations of the dying person, who was either consciously or subconsciously trained to expect heavenly scenery (etc.) by his cultural upbringing. This theory can be tested, in part, by examining the religiosity of the near-death experiencer. Ring (1980), for example, found that there was no correlation between religious belief - and negative correlation between prior knowledge of NDEs - and the person's actually having a full-blown near-death experience. But it could still be argued that since the entire culture uses heavenly imagery and metaphor, even the "non-religious" subjects had been unconsciously conditioned to project such experiences as they approached death. To further explore this claim, and to learn how culture-specific the characteristics of NDEs are, cross-cultural studies are necessary.

It is clear that many cultures believe in both the possibility of outof-body experiences (OBEs) and in the continuity of life after death. Tylor (1974) found such beliefs common among "primitive peoples"; and Shiels (1978) showed that almost all of seventy non-Western cultures he studied believed in OBEs of some sort. Gilmore (1981) has shown that visions of angels are prevalent in the Middle East, including Muslim, Zoroastrian, and Egyptian religious affiliations. But these studies, while important, tell us only about the belief-systems of non-Western peoples and fail to document that they actually ex- 
perience NDEs like those being studied in America.

The turn-of-the-century studies reported by Bozzano (1906) are among the first careful attempts to document NDEs, but they cannot be considered truly cross cultural since the European cases he cites are very much within the same cultural framework as modern America. Robert Crookall $(1964,1967,1968)$ also included a few reports of non-Western OBEs and NDEs in his numerous compendia, but these often lack careful documentation and reporting techniques. Osis and Haraldsson $(1961,1977)$ conducted the first attempts at cross-cultural comparison by gathering reports of Indian doctors and nurses who had witnessed NDEs in India. They found greater fear of dying, a larger incidence of religious imagery, and appropriately Hindu-flavored interpretations of apparitional figures. These studies are an important first step, but are frequently based on second-hand accounts some time after the NDE itself, and memories are notoriously subject to distortion. Other studies tangential to cross-cultural NDE research include Kalish's (1979) comparison of ethnic groups in Los Angeles and Audette's (in press) survey of the history of NDEs.

This paper is a preliminary report on the status of NDEs in Pure Land Buddhism in China, and is an important contribution to crosscultural research for several reasons. In some cases, like those of T'an-luan, the NDEs are clearly prior to personal knowledge of NDEs, and indeed become the cause of the holy man's search for religious explanation. In other cases, like those of Hui-yuan's disciples, we have deathbed records made at the time of death by first-person observers, along with time and dates for additional historical veridicality. In Pure Land Buddhism, we have a religion that not only admits of NDEs, but that is philosophically grounded upon their reality and accessibility to all men. Therefore it is hoped that such study of non-Western cultures and eras will be of value in determining the nature and universality of NDEs.

\section{PURE LAND BUDDHISM IN CHINA}

Few societies have placed greater importance on the reverence of ancestors - and therefore on funerals and concern for the dead - than the Chinese. Although Confucius tended to avoid discussions of the afterlife, and the Taoists envisioned it as a purified continuation of this bodily existence, there was a widespread acceptance of certain religious assumptions about the afterlife which lay the foundation for a Buddhist elaboration of it. The Chinese believed that the soul hovered around the body for some time until it was interred, and thence might haunt the house or ascend to other regions. The souls 
of at least the more famous generals or honorable rulers were expected to live on in a quasi-material paradise. The fate of the souls of average men could be influenced by the prayers of the living, during a period of forty-nine days after the death. Immediately after the death and funeral of one's father, fasting and prayer, penances and sackcloth were prescribed for the surviving sons, and even the most orthodox of Confucians undertook such mourning practices as part of their state duty. Pre-Buddhist traditions include numerous dreams of sick or dead men who visited heaven and then returned to earth, or of spirits returning to visit their loved ones.

Thus to the early Chinese mind, there was less of a conscious separation between the physical and the spiritual than most Western thinkers would tend to draw. Rather, man with all his organs and souls was simply another being on a vast cosmic continuum of gross and subtle matter, part of nature that included elements visible and invisible, but all real, detectable, and quasi-material (as opposed to transcendental or philosophically idealistic). It is little wonder, therefore, that the Buddhist notions of anatta, or of the illusoriness of material existence, were either rejected or misunderstood throughout the history of Buddhism in China.

\section{The Attraction of Buddhism to the Chinese}

After all that has been said about the great psychological gaps between Buddhism and Chinese thought: the conflicting life-ideals, different views of the cosmos, of death, of the family and the individual, of the soul - even of basic vocabulary - it is amazing that Buddhism ever made the headway it did in China. This progress was made, however, because certain (previously obscure) Buddhist sutras served to substantiate and "elaborate" details of Chinese cosmology which earlier Confucians or Taoists had not chosen to do. Moreover, the school of Buddhism that eventually won the hearts of the great masses of Chinese, the Pure Land (Ching T'u) School, painted pictures (metaphorically and literally) of a bejeweled Paradise to which any believer might aspire. Thus China transformed Buddhism not only from a world-denying to a world-affirming creed, but from a strenuous ascetic discipline for the spiritual elitc into a path of salvation open to the masses, who would be saved, not by their own efforts, but through their faith in their saviour.

Before examining the details of the Pure Land School, however, let us consider the assimilation of the basic notions of Buddhism: rebirth and nirvana. By the time Buddhism was approaching China, it had largely crystallized into two metaphysical schools, the 
Madhyamika nihilists and Yogacara idealists. Neither reflected the original teachings of the Buddha. Nor would the logical intricacies and philosophical subtleties of either be appreciated by the common Chinese layman. The Chinese were more impressed by what they took to be the affirmation of the continuity of a soul, from an oversimplified interpretation of the Buddhist doctrine of rebirth. Problems such as what (if anything) transmigrates, and what constitutes nirvana, so perplexing to Buddhist scholars ancient and modern, were largely ignored by most Chinese Buddhists, who developed the simplistic formulas that the doctrine of rebirth implies a permanent ongoing soil (shen), and that the notion of Nirvana implies a heaven beyond this earthly plane. ${ }^{1}$

The elaborate cosmology and "levels" of existence mentioned above which were embodied in popular Buddhism by the early centuries of the Christian era, if not in early Buddhism per se, gave flesh and bones to the previously vague Chinese conceptions of the nature of heavens and hells, and the ways men might arrive there. In accord with their hierarchical view of politics in this world, the Chinese elaborated a stratified hierarchy of heavens, hells, and their appropriate ministers, presided over by Yen-lo (Jap. Emma), a corruption of the Indian God of Death and the underworld, Yama. ${ }^{2}$ Yama was also taken to be the judge of all but the noblest of souls. Buddhist sutras that purported to report Gotama's instructions for the relief of the suffering of departed spirits (pretas) to Ananda, or that related the saving of sufferers in Hell by the vicarious prayer and merit of their surviving ancestors, were taken as an opportunity to further develop rituals for reverencing of the dead, such as at the Ulambana (Jap: O-bon) ceremonies. ${ }^{3}$ Ultimately, the notion that merit of one person could be transferred to another in the heavenly balance book led to the development of radically new Buddhist sects, based on the hope of salvation by faith and grace.

Amida pietism:

Even prior to the flourishing of the Amidist sects, there had grown into Mahayana Buddhism the idea that Gotama had been more than a mere mortal, but one of a veritable pantheon of Buddhas and bodhisattvas who had gained enlightenment through innumerable ages of meritorious deeds and rigorous practices. While explicitly human in origin, they had ascended in the minds of the common Mahayanists to a position quite analogous to the gods in the Hindu pantheon - indeed, the identities of various gods and bodhisattvas were frequently confused. Implicit in this new theology was the notion that such bodhisattvas could reach down to aid humans who 
besought their help, to share or impart their unlimited merits with their human believers, and reveal themselves physically (like Gotama) or through spiritual inspiration to their devotees. While strict Theravadins may see such views as an unforgivable corruption of the original intentions of the Buddha, the Mahayana approach did have the important merit of encouraging active good works among the people in society, holding as a model not the isolated ascetic but the ever-compassionate and helpful bodhisattva image.

Among the bodhisattvas, there were several whose roles and functions came to be associated with the hereafter and salvation of men, particularly Maitreya, Amida, and Ksitigarbha (Jap. Jizo). Maitreya is generally portrayed as the future Buddha who will come to teach and redeem the world after this depraved current period has come to an end. In the meantime, however, he presides over the Tusita heavens in the East and welcomes to those heavens after death those who have been devoted to him. Amida is the bodhisattva of infinite life and light who has come through many kalpas of self-sacrifice to preside over the Pure Land in the West, a kingdom free from defilements, where all beings who are born therein may expect nirvana in their next lifetime. Ksitigarbha, often depicted as a monk, does not govern an entire heaven of his own, but rescues and conducts pious souls from Hell, either back to this life, or to the Tusita or Pure Land heavens. By far the most prominent and important of these bodhisattvas, however, was Amida, and it is therefore to his particular position and role that we turn our attention.

The earliest "scriptural references" to the idea that one might be saved by the power of a bodhisattva rather than relying upon one's own abilities may be found in Nagarjuna's Dasabhumi Sutra, but no specification is made of any bodhisattva as being particularly relevant or efficacious there. The earliest sutras that specifically describe the land of bliss and the reign of Amida appear in Sanskrit and Chinese in the first and second century, respectively. The larger and smaller Sukhavati-vyuha sutra have become the major scriptural basis for the religion, supported by the Amitayurdhyana sutra and various fifthcentury commentaries by Vasubandhu, Kumarajiva, and the Pure Land patriarchs. Minor differences in the scriptures gave rise to different interpretations and factions particularly in the Japanese context, but for the most part the scriptures agree on the essentials. 4

The sutras relate that Dharmakara bodhisattva made forty-eight vows, half concerning the commitment to save all beings, and half concerning the nature of the heaven to which they should be reborn. Each of the vows concludes with the prayer, "May I not attain supreme enlightenment if I fail to accomplish this," and since it is a 
premise of the sutra that the bodhisattva Dharmakara has already completed his practice and attained enlightenment as Amida, the conditions of salvation and nature of heaven are therefore also taken to be established. These conditions are summarized in the eighteenth through twentieth vows, which may be rendered as follows:

(18) All the beings of ten directions with sincere profound faith who seek to be born in my land and call upon my name ten times, except those who have committed the five cardinal crimes or injured the true dharma, shall be born in my land.

(19)I will appear at the moment of death to all beings of the ten directions committed to Enlightenment and the practice of good deeds, who seek to be born in my land.

(20)All beings of the ten directions who hear my name, desire the Pure Land, and practice virtue in order to attain the Pure Land will succeed. 5

It should be emphasized that the success of all beings in achieving the Pure Land is not due to their own merits or efforts, but due solely to the efficacy of Amida's vows, in concert, admittedly, with the earnest longing and moral behavior of the devotees.

Other sections of the sutras make clear that Amida is a golden buddha of infinite light, who rules a heaven full of gold, jewels, and all manner of beautiful flowers and fountains, where days are spent in ceaseless praise and repetition of the sutras. The saved people sit on lotuses in the middle of a clear lake, on which they are reborn, and are blessed to live in this realm of no craving and no suffering (and no women).

Some of the obvious similarities with the heavenly imagery of the Christian church, or with the sun-god like imagery of the Zoroastrian or other Middle-Eastern religions, have led some scholars to postulate an origin for this pietistic cult in the Middle East. Takakusu (1947) refers to theories of origins in Christianity (Dahlmann), Manichaeism (Eliot), or the silk road in Central Asia (Reischauer) as failing to credit the original faith and religious experience of the Mahayanist tradition itself. 6 Although there was indeed occasional contact among Christians, Buddhists, and Zoroastrians in Central Asia, it seems hard to account for the flourishing of such a major tradition in China and Japan if it were merely the product of occasional missionaries and not the indigenous experience of the people. On the contrary, a survey of some of the major historical figures involved in the Pure Land traditions in China will serve to demonstrate that the imagery found therein was not borrowed from some Western tradition, but rather grew from the depths of their own religious life, a spontaneous, indigenous cultural phenomenon. 


\section{The First Transmission}

Although some Pure Land masters are traced back to the third century A.D. ${ }^{7}$, it was not until the fourth century that a groundswell of popular thought leaned towards the acceptance of this supernatural, deific figure of Amida and his paradise as an acceptable path to salvation. 'Tradition has it that Tao'an, the learned monk who was first to formally make vows for salvation, learned of the other-power salvation tradition from an Indian (Sanskrit) scholar visiting China. 8 It is equally arguable that Tao-an's familiarity with and interest in Maitreya grew not from a particular scripture or scholar, but from the oral traditions that were already becoming popular in China at that time. ${ }^{9}$ Tao-an is primarily remembered as a great translator, commentator, and exegete of the wealth of Sanskrit literature that was pouring into China in the fourth century, and he was highly familiar with many of the more intricate doctrines and self-reliant disciplines of Indian Buddhism. It is therefore all the more remarkable that he should have sought salvation by faith rather than through his own works. Zurcher (1959) illuminates the interesting fact that Maitreya was seen as a patron of exegetes, and Tao-an was almost pathologically concerned with not making mistakes in his difficult exegeses. 10

It was to Maitreya, then, and not to Amida, that Tao-an devoted himself, and in the year 370 he assembled seven of his pupils, who made a collective vow to be reborn in the Tusita heaven. This vow was probably accompanied by meditations to enable the believers to catch a glimpse of the Tusita heavens even while still in this earth, 11 but it is also clear that the primary hope was that of rebirth in the heavens after death in this body. We cannot be certain, but it seems quite probable that Tao-an's disciple Hui-yuan was among those who vowed before Maitreya at Hsiang-yang. ${ }^{12}$ In any event, the parallels between this Maitreya-devotionalism and Hui-yuan's subsequent Amida-pietism are too blatant to dismiss.

De Visser (1935) explains it this way:

There was a close connection between the Maitreya and Amitabha doctrines, since both of them were "easy ways" towards Nirvana ... ; they were based on the power of another....; they were gates of the Pure Land instead of the "Road of the Aryas" ... In China, Tao-an was the first to worship Maitreya and pray to be reborn in the Tushita heaven; and when he died in A.D. 385, a strange priest appeared and pointed to the Northwest, where the clouds opened and a beautiful heaven became visible to his dying eyes. 13

Whether or not this story bears the marks of hagiography, it is important because it illustrates the strong belief that believers would 
meet the bodhisattvic object of their devotions face to face, either through meditations, or indeed while on their deathbeds. This is a pattern that we shall see reiterated time and again. It seems that the cult of Maitreya was continued by some of Tao-an's disciples after his death, but the groundswell of popular opinion was more interested in the salvation offered by the compassionate Amida than by the patron of scholars, Maitreya. ${ }^{14}$ This may have been one of the factors that led Tao-an's disciple Hui-yuan to abandon Maitreyaworship in preference to Amida-pietism, and to summon not only priests and translators but eminent lay Buddhists to join him in his devotional pledge.

In addition to being a highly competent Buddhist intellect, Huiyuan had studied Confucianism and Taoism in his youth, and the mountain on which he founded his famous monastery (Lu-shan) had been famous for centuries previous as the abode of animistic gods and Taoist immortals. Hui-yuan attracted to his mountain hermitage many bright young scholars who preferred the peaceful meditative existence to the competition of official circles, 15 particularly in that warring period when officials' lives were anything but secure. Zurcher (1959) characterizes Hui-yuan's disciples as young artistic gentry literati, and although he only discusses the lives of a small handful, there were apparently more than a hundred of such disciples at Lu-shan around 400 A.D.

It was on September 11, 402, that Hui-yuan gathered 123 of his followers, including both monks and laymen, before an image of the Buddha Amitabha. Together they vowed to be devoted to Amitabha, to strive for rebirth in the Pure Land, and to refrain from entering the Pure Land alone without attempting to help all their comrades to attain the same goal. This marked the founding of the White Lotus Society, the first formal school of Amida pietism (perhaps because it is into white lotuses that people hope to be reborn in the Pure Land). The ceremony was accompanied by the solemn reading of a text composed by Hui-yuan's disciple Liu Ch'eng-chih, by the burning of incense, offering of flowers to the image of Amida, and the pledging of commitment to the pact. 16

As in the case of his master Tao-an, Hui-yuan sought contact with the bodhisattva (Amida in this case) not only at death, but through meditations while alive. The use of carved and painted images supplemented meditative practices to better enable the devotees to experience visions of their saviour even before death. We know that Hui-yuan himself frequently had such visions, for he asked Kumarajiva in a letter whether the apparitions of Amida came from the mind of the meditator or from some more objective source. 17 We also know 
that Hui-yuan was "often ill" in his later years (he was seventy at the time of the vow). Although this might point to the possibility that such visions were products of a fevered brain, we must balance this consideration with the facts that Hui-yuan was still lucidly capable of rigorous physical and academic practices, that he believed strongly enough in the reality of the Pure Land to commit an entire community to its achievement, and that many of his disciples also had similar visions, with or without accompanying illness. It is therefore equally possible that an earlier illness occasioned his first visions or brush with the mystical Buddha of infinite light, and that he thereupon developed Buddhist practices to substantiate and perpetuate this vision.

Apart from his Pure Land devotionalism, Hui-yuan wrote several treatises in which he treats the nature of the soul in a very concrete manner:

As for the soul, it responds perfectly and has no master, it is extremely mysterious and nameless. It moves in response to things, and it functions in individual destinies. Though it responds to (physical) things, it is not a thing; therefore the thing may change but it (the soul) does not perish. It is attached to individual destinies (lives) but it is not bound to them, so that it is not exhausted when the destiny is terminated... the soul has the power of moving subtly. 18

He attacks the Taoists who try to make man's body eternal, but then suggests that it is in fact the soul that is eternal, capable of perception, movement, and above the wheel of life and death.19 As mentioned earlier, this would seem a very un-Buddhistic approach to the Indian Buddhist of nine centuries earlier, but it was the only way in which the Chinese could make sense of the notions of karma and rebirth, lacking the sophisticated process philosophy the early Indians had had. From these detailed descriptions of the soul as a permanent, subtly moving entity, we may also be led to wonder whether Hui-yuan's meditations had not led him to the point where he actually believed his soul occasionally detached from his given body. 20

Whether or not Hui-yuan himself had a remarkable deathbed or out-of-body experience, we have reports of the deaths of several of his disciples who preceded him. Liu Ch'eng-chih, the student who had composed the vow of the White Lotus Society, demonstrated exceptional zeal in meditation. It is said that he could see the Pure Land when in meditation, that he saw the Buddha in the air in front of him whenever he encountered a statue, and that he constantly encouraged the monks around him to recite the Pure Land Sutras. Zealously eager to leave this world for the next, he predicted the 
date of his own death, and passed away while sitting upright facing west, after bidding farewell to his friends, and without a trace of disease, suffering, or other natural cause of death. These accounts seem to imply that he had a vision of the Pure Land in his last moments, and that the cause of death was his own excellence in being admitted into the Pure Land. ${ }^{21}$ Seng-chi was the next famous disciple to pass away, and his death too is recorded in some detail for its unusual circumstances. Because of its parallels with modern deathbed research, it is worth recounting in full here:

He was afflicted by a grave disease, and then he devoutly wanted the Western Country ... he asked the monks to gather at night and recite the Sukhavativyuha for his sake. During the fifth watch, Chi handed the candle to his fellow-students and requested them to go around with it among the monks. Then he lay down for a moment, and in his dream he saw himself proceed through the void, (still) holding the candle, and he beheld the Buddha Amitabha, who took him up and placed him (or: the candle?) on the palm of his hand, and (in this position) he went through the whole (universe) in all directions (or: its light spread everywhere in all directions). Suddenly he woke up and told everything about his dream to those who nursed him, who were grieved (at this sign of approaching death) and yet consoled (at his vision). When he examined his own body, there were no (longer any signs of) disease and suffering whatsoever.

The following night, he suddenly sought for his sandals and stood up, his eyes (looking into) the void in anticipation, as if he was seeing something. A moment later he lay down again, with a joy ful expression on his face. Then he said to those who stood at the side of his bed: "I must go," and when he had turned over on his right side, his life-breath and his words became simultaneously extinguished. 22

A similar death is reported for the star disciple Hui-yung in 414:

Although his disease was very grave, he (still) assiduously observed the monastic rules ... Shortly afterwards, he suddenly asked for his clothes, folded his hands, sought for his sandals, and wanted to stand up as if he was seeing something. When the monks, all startled, asked him (what he saw), he replied: "The Buddha is coming!" When he had finished speaking he died. 23

These historic accounts should make clear that there were famous people, whose deathbed scenes were witnessed by many friends, carefully recorded, and widely reported, who experienced an apparition of the Buddha Amida at their deathbeds. Such facts of religious experience were not only sufficient to bolster and encourage the spread of Pure Land Buddhism throughout China during the following centuries, but they also demonstrate that the belief in Amida had its basis in personal, Buddhist experience of the Chinese, and was not merely a doctrinal or artistic distortion of Christianity or Manichaeism. The lives of later patriarchs point to similar experiential bases. 


\section{The Second Transmission}

Although the White Lotus Society continued to enjoy a following for many centuries, the next major development in this history of Pure Land thought came from a completely separate and unrelated source. This time, the impetus came to north China, where a scholar more than fifty years old, by the name of T'an-luan, had a remarkable conversion experience. Ch'en summarizes it as follows:

On one occasion he recovered from a serious illness when he suddenly saw a golden gate open before him. With this experience, he decided to search for an elixir that would bring about everlasting life ... on his way back to the north he met the Buddhist monk Bodhiruci, who told him that in Buddhism there was a formula for attaining everlasting life that was superior to that of the Taoist. Upon being asked to reveal the formula, Bodhiruci taught him the texts of the Pure Land school, where upon T'anluan became so convinced that he discarded the Taoist texts which he had obtained and concentrated on the attainment of the western Paradise. This conversion took place about 530 , and for the remainder of his life he devoted all his time to the propagation of the Pure Land tenets. 24

Several observations warrant emphasis at this point. First of all, we have here the case of a man whose whole view of life is changed by "seeing a golden gate" at the end of a serious illness. While he had not been especially famous as a religious figure prior to that point, suddenly, at the advanced age of fifty-two, he began a pilgrimage from the north to the south of China to seek the religious truth. And when he thought he had found it, he forsook all else in order to preach it to the Chinese world. This would reinforce the tremendous impact of the religious experience he underwent.

Secondly, we should note that he threw away his Taoist (Chinese!) texts, acquired only after great effort, for the little known and foreign Buddhist scriptures Bodhiruci was just then introducing from India. Why should foreign scriptures have had precedence over his native Chinese tradition - especially scriptures that had not yet even won the respect of the majority of Chinese Buddhists? Surely, in meeting Bodhiruci, T'an-luan must have told him of his disease, his recovery, the golden gate, and his search for the way to eternal life. This conversation could not help but to have jarred Bodhiruci's memory about the sutras of the Pure Land, with its golden gates and heavenly interior, governed by Amida. Although these were but a minor part of the sutras he was carrying and translating, they clearly seemed the ones most relevant to the search of his new acquaintance, T'an-luan. For his part, T'an-luan, hearing of the similarity of the Pure Land sutras to his own experience, undoubtedly concluded that here was the explanation of the phenomenon he had witnessed, 
and this was the reason he so readily forsook the Chinese Taoist tradition for an otherwise relatively minor tradition in Indian Buddhism.

T'an-luan particularly emphasized three of the forty-eight vows: the eighteenth (that all beings who call on Amida's name will obtain the Pure Land); the eleventh (that all beings in the Pure Land shall be on the path to nirvana); and twenty-second (that bodhisattvas of other heavens who come to the Pure Land will experience there their last rebirth [prior to nirvana] unless they choose to be reborn on earth to save other sentient beings). ${ }^{25}$ In the eighteenth vow, we find the doctrinal basis for chanting the name Amida, which T'an-luan initiated and advocated, and also the foundation of tariki, the faith that one is saved not by his own but by divine power. This eighteenth vow was used again by later patriarchs to justify and establish their own faith. But the eleventh and twenty-second vows have been largely overlooked by later Pure Land Buddhists, even though their founder T'an-luan emphasized them.

Why were these vows particularly important to T'an-luan? By calling the Pure Land, if not nirvana, the gateway to nirvana, and equating Amida with the ultimate reality, ${ }^{26}$ T'an-luan deemphasized the differences between Pure Land and other Buddhist schools, and concretized the Chinese understanding of such otherwise abstract terms. Experientially, we may ask whether perhaps he had felt that he was on the threshold of the absolute when he had his golden gate vision at the end of his illness. By stressing the twenty-second vow, T'an-luan pointed to two other convictions of his which later thinkers ignored. The first is that other bodhisattvas (and holy men) could enter the Pure Land, without necessarily undertaking specifically Pure Land practices. ${ }^{27}$ The other point is that men can return from the Pure Land to teach each other here in this world. Since his personal brush with death, perhaps T'an-luan felt that he had almost entered the Pure Land himself (without specifically Pure Land-type preparation) and was "born again" to teach men of this realm.

Although T'an-luan taught fervently for a dozen years after his conversion, contributing to the spread of Pure Land Buddhism in northern China, it was not an immediate student, but a "spiritual disciple" born several decades later who was to take up his mantle as Pure Land patriarch. Tao-ch'o was born in 562 in a period of social and political upheaval and was convinced that he was living in the predicted period of the latter law, in which the dharma of Buddha had degenerated. Inspired by an inscription on the tomb of T'an-luan, Tao-ch'o entered the monastery where he had taught and seriously undertook the Pure Land meditations. Possessing a calm and quiet 
nature, a peaceful smile, and an ability to relate to commoners as well as nobility, Tao-ch'o soon attracted a large following, and became famous for temple-building and statue-erecting.

At the age of sixty-five, aged and sick, he felt himself to be on his deathbed, and summoned his disciples and many followers to recite the sutras. Thereupon T'an-luan appeared to him, and in a voice heard by all present, commanded that Tao-ch'o must continue to teach people for many years. It is said that flowers fell from heaven, which were carefully preserved by his followers. From that day on, Tao-ch'o became progressively healthier, even regaining another set of teeth, and continued to teach for almost two decades, living to the rare age of eighty-three. ${ }^{28}$ Thereafter he was revered almost as a god by lay and priestly disciples alike.

Let us turn briefly to Tao-ch'o's writings to better understand his visions. Tao-ch'o held that Pure Land practices included both meditations and calling on the name of Amida Buddha. In his An-le-chi, he is particularly intent upon denying the contemporary allegations that visions of the Pure Land are purely subjective and psychological, declaring them to be sambhoga-kaya - subtle but real matter. 29

Tao-ch'o's disciple Shan-tao was held in far less estimation than Tao-ch'o by his contemporaries, so we know few details of his life. Writing numerous picturesque and emotional commentaries on the Meditation Sutra, he outlined five activities that could lead to birth in the Pure Land: name-chanting, sutra-chanting, meditations, imageworship, and hymn-singing. ${ }^{30}$ The important thing to note here is that Shan-tao, although often distorted by later interpreters, placed equally great stress on the meditative visualization of the Pure Land and concurred with his master Tao-ch'o on the objective reality of those visions. Shan-tao lived a frugal beggar's life, contrasting with the quiet but ample life-style of his master; he was often poor, sick, and troubled by sin, and clearly held his dreams of the Pure Land to be more real than the miserable world around him in waking life. (This is in sharp contrast to Tao-ch'o, who believed that the two were on a continuum, not contrary.) We do know that Shan-tao's insistence on the preferability and availability of the Pure Land to this world led at least one follower to suicide by jumping from a tree in front of his monastery. Tsukamoto (1968) hints in other ways at Shan-tao's "dark past" and suggests that the legend may be true that Shan-tao himself committed suicide to end his days of suffering and obtain the Pure Land. 31

The Third Transmission

Hsin Hiu-jih (who has come to be known as Tzu-min) was born in 
680 , only shortly after Shan-tao's passing, but he was not connected to the T'an-luan-Shan-tao tradition. It was apparently a desire to travel that motivated Tzu-min above all else, for he journeyed for almost twenty years, first by sea to India, and then throughout the subcontinent. His biographers relate that he was inspired by stories of Amida while in India - so much so, that he decided to devote the remainder of his life to spreading the gospel of the Pure Land and the practice of nien-fo (Jap. nembutsu) among the masses in China. 32 Fujiwara (1974) calls Tzu-min a "sincere aspirant for the Pure Land," who rejected meditations merely on the void (of Ch'an Buddhism). He studied and respected Shan-tao's works, and stressed, like Tao-ch'o, that the visions of the Pure Land obtained in meditation were objectively real and not psychological illusions.

Tzu-min's star pupil, Ch'eng-yuan, had begun his training in the Zen tradition, then switched to T'ien-tai and Vinaya Buddhism, and finally,

He happened to hear that Tzu-min had come from Chang-an to Kuangchou to preach the Pure Land teaching. Thus Ch'eng-yuan paid Tzu-min a visit and immediately took refuge in the teaching of the Nembutsu. After returning to Nan-yueh, he established a Nembutsu center called Mi-t'o-tai, and started a vigorous missionary movement among the many people who gathered there from remote areas. 33

The striking thing to be noticed about the biographies of both of these men is that they studied Buddhism for many years before becoming closely acquainted with the Pure Land tradition. Upon making the acquaintance of the Pure Land tradition, however, they "suddenly" decided to devote their entire lives to it, and they started a new period of highly active temple-building and nien-fo proselytizing. We cannot help but surmise that there must have been some important personal experiences behind this sudden conversion, for a merely intellectual change of mind could hardly account for so drastic a change of mind and of life-style.

The role of personal experience in the conversion of Fa-chao is even clearer. Although his early history remains in some doubt, it seems clear that he entered a monastery on Mount Lu-shan, where Hui-yuan had first formed the White Lotus Society 350 years earlier. While in meditation on the nien-fo, he had a vision of Ch'eng-yuan, and left Lu-shan for Nan-yueh to join Ch'eng-yuan, who had remarkable powers and special virtues, as he later reported to the emperor. 34 He had many remarkable visions while practicing the constantlywalking samadhi meditations under Ch'eng-yuan, and felt that he had personally been taught a five-tone nien-fo chant by Amida himself, while visiting the Pure Land in meditation. 35 
He entered samadhi, being born in the Pure Land with his physical body, he personally listened to the sounds of water, birds and trees in praise of the Buddha. After coming out of the samadhi, he introduced the sound of the dharma to Wu-t'ai-shan.

He then moved to Wu-t'ai-shan and established a temple for the chanting of five-toned nien-fo. The story has it that the Emperor heard the nien-fo drifting into his palace from the northeast, sent a messenger to seek the source of the sound, and discovered a huge assembly of people surrounding $\mathrm{Fa}$-chao, chanting the nien-fo (but at a great distance from the palace). $36 \mathrm{Fa}$-chao was thereupon invited to the palace and honored, given royal patronage, encouraged to write numerous texts on the nien-fo and to teach the imperial court to praise the name of Buddha in those five musical tones. Returning to his mound Wu-t'ai-shan, he established the Chu-lin-ssu temple where he had formerly experienced visions of Amida, and it was there that the pilgrim Eshin (later master Jikaku) from Japan met his disciples and observed his nien-fo practices. 37

As we thus view the history of the several transmissions and the "patriarchs" of Pure Land Buddhism within them, certain common elements stand out before us. In many cases, the patriarch was either a sickly fellow or in fact had an experience on his deathbed after which he revived to preach the Pure Land for many years. For those patriarchs whose conversion was less dramatic (or of whom we have no clear record), we can at least assert that the conversion involved a great leap of faith, a change of life-style from quiet scholarship to dramatic preaching, and promulgation of little-known Indian sutras over more popular Chinese Ch'an or T'ien-tai Canons. Unlike their Japanese followers, these Chinese Pure Land patriarchs stressed that the Pure Land may be seen in this life while in samadhi-meditation, and notably, that the reality of such visions or dreams was equal to (or greater than) the reality of the waking world.

Moreover, although separated by hundreds of miles and hundreds of years, patriarchs in each of these traditions described similar visions and expected similar phenomena in their Pure Land rebirths. To some degree this similarity might be attributed to their using the same sorts of sutras as the basis for their meditations, and to their living in the same culture (although the language and customs of north and south were very different). On the other hand, the fact that some of them apparently sought the Pure Land tradition after having had visions while very ill (either of the Pure Land itself or of Pure Land masters) might lead us to suspect that more was occurring here than mere psychological projection on the part of would-be believers. Historically speaking, these facts constitute an 
important refutation to the theory that the Pure Land tradition was necessarily borrowed from some Near Eastern source. Philosophically speaking, they add important evidence of the cross-cultural continuity of deathbed experiences.

\section{NOTES}

1. Smith (1973), pp. 291-298.

2. Reichelt (1928), pp. 82-84.

3. Ibid., pp. 92,115 .

4. Fujiwara (1974), pp. 28-35.

5. Matsunaga (1976), pp. 30; cf. pp. 22-23 for preceding ideas.

6. Takakusu (1947), p. 167.

7. Ch'en (1964), p. 342f.

8. Zurcher (1959), pp. 180-183.

9. Ito (1923), pp. 192-3.

10. Zurcher, p. 194.

11. Demieville (1954), pp. 377-390.

12. Zurcher, p. 195.

13. deVisser (1935), p. 318.

14. See also Fung (1948), pp. 244-246.

15. Zurcher, p. 217.

16. Ibid., pp. 218-220.

17. Ibid., pp. 240-253.

18. Ch'en, p. 111.

19. Smith, pp. 295-297.

20. Zurcher, pp. 240-253.

21. Cf. parallels in Reichelt, p. 169; Zurcher, p. 221.

22. Liebenthal (1950), p. 251.

23. Zurcher, p. 222.

24. Ch'en, p. 108 , p. 344.

25. Fujiwara, p. 57.

26. Matsunaga, p. 25.

27. Ibid., pp. $25,40$.

28. Tsukamoto (1968), pp. 106, 278.

29. Matsunaga, p. 26; Fujiwara, p. 62.

30. Matsunaga, p. 27; Ch'en, p. 346.

31. Tsukamoto, pp. 283, 288.

32. Ch'en, pp. 347-8.

33. Fujiwara, pp. 130-134.

34. Chih-p'an (1966), pp. 69, 73 cf. notes.

35. Fujiwara, pp. 145-6. 
36. Chih-p'an, p. 72.

37. Fujiwara, p. 135.

\section{REFERENCES}

Audette, J. R. Historical perspectives on near death episodes and experiences. In C. Lundahl (Ed.), A Collection of Near-Death Research Readings. Chicago: Nelson-Hall, in press.

Bozzano, E. Apparitions of deceased persons at death-beds. Annals of Psychical Science, 1906, V, 67-100.

Ch'en, K.K.S. Buddhism in China. Princeton: Princeton University Press, 1964.

Chih-p'an. A Chronicle of Buddhism in China, 581-960 A.D. trans. and ed., J. Y. Hua. Santiniketan: Visva-bharati, 1966.

Crookall, R. Events on the Threshold of the Afterlife. Moradabad: Darshana International, 1967.

---_--. Mechanism of Astral Projection. Moradabad: Darshana International, 1968.

------. More Astral Projections. London: Aquarian Press, 1964.

Demieville, P. In Bulletin de l'Ecole Francaise d'Extreme Orient, 1954, XLIV, 377-390.

deVisser, M. W. Ancient Buddhism in Japan. Leiden: E. J. Brill, 1935. Fujiwara, R. The Way to Nirvana. Tokyo: Kyoiku Shinchosha, 1974. Fung, Y. A Short History of Chinese Philosophy. Trans. and ed., D. Bodde. New York: Macmillan, 1948.

Gilmore, G. D. Angels, Angels, Everywhere. New York: Pilgrim Press, 1981.

Ito, G. Shina Bukkyo Seishi (True History of Chinese Buddhism). Tokyo, 1923.

Kalish, R. A. Contacting the dead: does group identification matter? In R. Kastenbaum (Ed.), Between Life and Death. New York: Springer, 1979, 61-72.

Liebenthal, W. Shih Hui-Yuan's Buddhism as set forth in his writings. Journal of the American Oriental Society, 1950, p. 251.

Matsunaga, D. Foundation of Japanese Buddhism, v. 11. Tokyo: Buddhist Books International, 1976.

Moody, R. A. Jr. Life After Life. Atlanta: Mockingbird Books, 1975. Osis, K., and Haraldsson, E. Deathbed Observations by Physicians and Nurses. New York: Parapsychology Foundation, 1961.

-___- At the Hour of Death. New York: Avon Books, 1977.

Reichelt, K. L. Truth and Tradition in Chinese Buddhism. Trans. K. V. Bugge. New York: Paragon Book Reprints, 1968, (originally Shanghai, 1928). 
Ring, K. Life At Death. New York: Coward, McCann, \& Geoghegan, 1980.

Shiels, D. A cross-cultural study of beliefs in out-of-the-body experiences, waking and sleeping. Journal of the Society for Psychical Research, 1978, IL, 697-741.

Smith, D. H. Conflicting ideas of salvation in A.D. 5th century China. In E. J. Sharpe \& J. R. Hinnells (Eds.), Man and His Salvation. Manchester: Manchester University Press, 1973.

Takakusu, J. The Essentials of Buddhist Philosophy. Honolulu: University Press of Hawaii, 1947.

Tsukamoto, Z. Bukkyo no Shiso, v. VIII, Chugoku Jodo. (Buddhist Thought, v. VIII, Chinese Pure Land). Tokyo: Kadokawa Shoten, 1968.

Tylor, E. B. Primitive Culture, v. II. New York: Henry Holt, 1974.

Zurcher, E. The Buddhist Conquest of China. Leiden: E. J. Brill, 1959.

Requests for reprints to:

Carl B. Becker

Department of Philosophy

Southern Illinois University

Carbondale, Illinois 62901 